\title{
GMR
}

\section{Generic relationships among Molluginaceae inferred from a molecular phylogenetic analysis of the matK gene}

\author{
M.A. Ali ${ }^{1 *}$, J. Lee ${ }^{2 *}$ and F. Al-Hemaid ${ }^{1}$ \\ ${ }^{1}$ Department of Botany and Microbiology, College of Science, \\ King Saud University, Riyadh, Saudi Arabia \\ ${ }^{2}$ Department of Environment and Forest Resources, \\ Chungnam National University, Yuseong, Daejeon, Republic of Korea \\ *These authors contributed equally to this study. \\ Corresponding authors: M.A. Ali / J. Lee \\ E-mail: alimohammad@ksu.edu.sa / jklee6@daum.net
}

Genet. Mol. Res. 16 (2): gmr16029295

Received September 16, 2016

Accepted May 11, 2017

Published June 29, 2017

DOI http://dx.doi.org/10.4238/gmr16029295

Copyright $(2017$ The Authors. This is an open-access article distributed under the terms of the Creative Commons Attribution ShareAlike (CC BY-SA) 4.0 License.

\begin{abstract}
The family Molluginaceae (order Caryophyllales) is considered polyphyletic based on the photosynthetic pathway, $\mathrm{C}_{4}$ evolution, and phylogeny of the family. This inference was made based on photosynthetic, anatomical, and molecular datasets. The generic circumscription of this family has greatly been changed owing to the placement of several of its genera into the Caryophyllaceae, Microteaceae, Lophiocarpaceae, and Limeaceae families. However, the generic relationships are largely unknown. By virtue of high substitution rates within the species and the ability to resolve the phylogenetic position of morphologically very closely related species and species complexes, the matK gene has emerged as one of the potential chloroplast DNA molecular markers in plant molecular phylogenetics and DNA barcoding studies. We herein used molecular phylogenetic analyses of matK gene sequences using maximum parsimony and maximum likelihood analyses to infer the generic
\end{abstract}

Genetics and Molecular Research 16 (2): gmr16029295 
relationships among currently recognized genera circumscribed under the family Molluginaceae. The resulting phylogenetic tree confirmed the polyphyly of the family Molluginaceae. The genus Hypertelis was found at the base of the Molluginaceae clade. The genus Glinus was close to Glischrothamnus and Mollugo, Suessenguthiella was close to Coelanthum and Pharnaceum, whereas Polpoda grouped with Adenogramma and Psammotropha. The present study constitutes a robust investigation of the molecular phylogenetic relationships among members of the family Molluginaceae. Future study should combine by combined analyses of morphological characters and multiple nuclear and chloroplast DNA sequences with a more comprehensive taxon sampling of the family Molluginaceae.

Key words: Molluginaceae; matK; Phylogeny; Generic relationships

\section{INTRODUCTION}

The order Caryophyllales comprises about 30 families, recognized under the order Caryophyllales in the core eudicot clade of angiosperm phylogeny (Angiosperm Phylogeny Group, 2009). Most of the families in this order were given taxonomic rank of family during the last two decades (Sukhorukov et al., 2015). On the basis of presence of anthocyanin and other morphological characters, the family Molluginaceae was segregated from Aizoaceae (Endress and Bittrich, 1993). Results of molecular phylogenetic analyses revealed that the family Molluginaceae is polyphyletic (Cuénoud et al., 2002; Angiosperm Phylogeny Group, 2009). Several genera previously treated under the family Molluginaceae have therefore been shifted to other families. For example, the genus Corbichonia is now in the family Lophiocarpaceae, Limeum in Limeaceae, and Corrigiola with Telephium are in Caryophyllaceae (Endress and Bittrich, 1993; Cuénoud et al., 2002; Arakaki et al., 2011; Brockington et al., 2011; Christin et al., 2011; Christenhusz et al., 2014). As per the taxonomic treatment of Angiosperm Phylogeny Group (2009), the family Molluginaceae comprises ca. 90 species under ca. 10 genera (viz., Adenogramma Reichenbach, Coelanthum E. Meyer, Glinus L., Glischrothamnus Pilg, Hypertelis E. Meyer, Mollugo L., Pharnaceum L., Polpoda C. Presl, Psammotropha Ecklund \& Zeyher, and Suessenguthiella Friedrich). These species are found in tropical to warm temperate regions, especially in southern Africa and northeast Brazil.

The polyphyly of the family Molluginaceae was established on the basis of photosynthetic, anatomical, and molecular datasets. This changed the generic circumscription greatly owing to the placement of several of its genera into family Caryophyllaceae, Microteaceae, Lophiocarpaceae, and Limeaceae (Christenhusz et al., 2014). The relationships among the genera in this family based on molecular phylogenetic analyses are largely lacking (Cuénoud et al., 2002, Angiosperm Phylogeny Group, 2009; Lee et al., 2013; Christenhusz et al., 2014). The maturaseK (matK) 1500 bp long chloroplast-encoded, rapidly evolving gene nested between the 5' and 3' exons of trnK, tRNA-lysine in the large single copy region of the chloroplast genome (Sugita et al., 1985). The rate of nucleotide substitution in the matK is six times higher than the amino acid substitution rate, and three times higher than that of the large subunit of Rubisco (Johnson and Soltis, 1994; Olmstead and Palmer, 1994). The high nucleotide and amino acid substitution rates of the matK provide sound phylogenetic signals

Genetics and Molecular Research 16 (2): gmr16029295 
for resolving evolutionary relationships among flowering plants also at lower taxonomic levels (Hilu and Liang, 1997; Soltis and Soltis, 1998; Hilu et al., 2003) and plant DNA barcoding (Ajmal Ali et al., 2014). The present study aimed to analyze matK sequences of representative genera of the family Molluginaceae in order to infer the generic relationships.

\section{MATERIAL AND METHODS}

\section{Data collection}

The chloroplast gene matK is one of the most variable coding genes of angiosperms (Sugita et al., 1985; Johnson and Soltis, 1994; Olmstead and Palmer, 1994). matK has very high evolutionary rate, and thus finds its application in plant DNA barcoding (Ajmal Ali et al., 2014; Kar et al., 2015) and molecular phylogenetic reconstructions at both lower and higher taxonomic levels (Hilu and Liang, 1997; Soltis and Soltis, 1998; Hilu et al., 2003). Therefore, the DNA sequence of the entire coding region of matK of 10 species belonging to 10 different genera recognized under Molluginaceae as per treatment of angiosperm phylogeny (Angiosperm Phylogeny Group, 2009) were retrieved from GenBank, National Centre for Biotechnology Information (NCBI) (Table 1). To compare the Molluginaceae matK sequences, the sequences of Acanthocalycium spiniflorum (family Cactaceae) and Portulaca oleracea (family Portulacaceae) were also retrieved from GenBank. The family Molluginaceae is supported as the sister group of Portulacineae (Nyffeler et al., 2008; Nyffeler and Eggli, 2010). Therefore, the matK sequence of Alluaudia procera (family Didiereaceae) was used as outgroup in the molecular phylogenetic analyses. The matK sequence of outgroup were also retrieved from NCBI (Table 1).

Table 1. The GenBank accession No. and span of matK gene sequences for all taxa included in the molecular phylogenetic analyses to infer the generic relationships among members of the family Molluginaceae.

\begin{tabular}{|c|c|c|c|c|}
\hline Group & & Taxon & GenBank accession No. & matK span \\
\hline \multicolumn{5}{|l|}{ Ingroup } \\
\hline \multicolumn{5}{|l|}{ Family } \\
\hline \multirow[t]{10}{*}{ Molluginaceae } & 1. & Adenogramma teretifolia (Thunb.) Adamson & FN825691 & $609-2159$ \\
\hline & 2. & Coelanthum parviflorum Fenzl & FN825759 & $1428-2194$ \\
\hline & 3. & Glinus oppositifolius (L.) Aug.DC. & FN825696 & $642-2177$ \\
\hline & 4. & Glischrothamnus ulei Pilg. & FN825699 & $593-1614$ \\
\hline & 5. & Hypertelis spergulacea E. Mey. ex Fenzl & FN825701 & $638-2197$ \\
\hline & 6. & Mollugo verticillata $\mathrm{L}$. & JQ844142 & $623-2167$ \\
\hline & 7. & Pharnaceum lanuginosum J.C. Manning \& Goldblatt & FN825752 & $605-2152$ \\
\hline & 8. & Polpoda capensis C. Presl & FN825753 & $632-2179$ \\
\hline & 9. & Psammotropha quadrangularis (L. f.) Fenzl & FN825755 & $611-2161$ \\
\hline & 10. & Suessenguthiella scleranthoides Friedr. & FN825756 & $636-2183$ \\
\hline Cactaceae & 11. & Acanthocalycium spiniflorum (K.Schum.) Backeb. & HM041644 & $614-2131$ \\
\hline Portulacaceae & 12. & Portulaca oleracea L. & HQ620836 & $1-1521$ \\
\hline \multicolumn{5}{|l|}{ Outgroup } \\
\hline Didiereaceae & 13. & Alluaudia procera (Drake) Drake & HQ620842 & $598-2127$ \\
\hline
\end{tabular}

\section{Molecular phylogenetic analyses}

The FASTA format of matK sequences of taxa included in the molecular phylogenetic analyses was aligned using ClustalX 1.81 (Thompson et al., 1997). Gaps in the sequence alignment were considered as missing data in the analyses. The generated aligned sequence data matrix was saved in nexus format. The data were then imported to MEGA5 (Tamura 
et al., 2011) and subsequently converted to MEGA format. We then performed maximum parsimony (MP) (Eck and Dayhoff, 1966; Felsenstein, 1985; Nei and Kumar, 2000) and maximum likelihood (ML) analysed in MEGA5 (Tamura et al., 2011).

\section{RESULTS AND DISCUSSION}

The MP analysis of the matK sequences resulted in to three maximally parsimonious trees (MPTs) with a tree length of 138 , a consistency index of 0.755 , a retention index of 0.851 , and the composite index of 0.703 for all sites and 0.348 for parsimony-informative sites (Figure 1). There were a total of 246 positions in the final dataset, of which 55 were parsimony informative. The ML analysis resulted in to tree with the highest log likelihood -1099.02 (Figure 2).

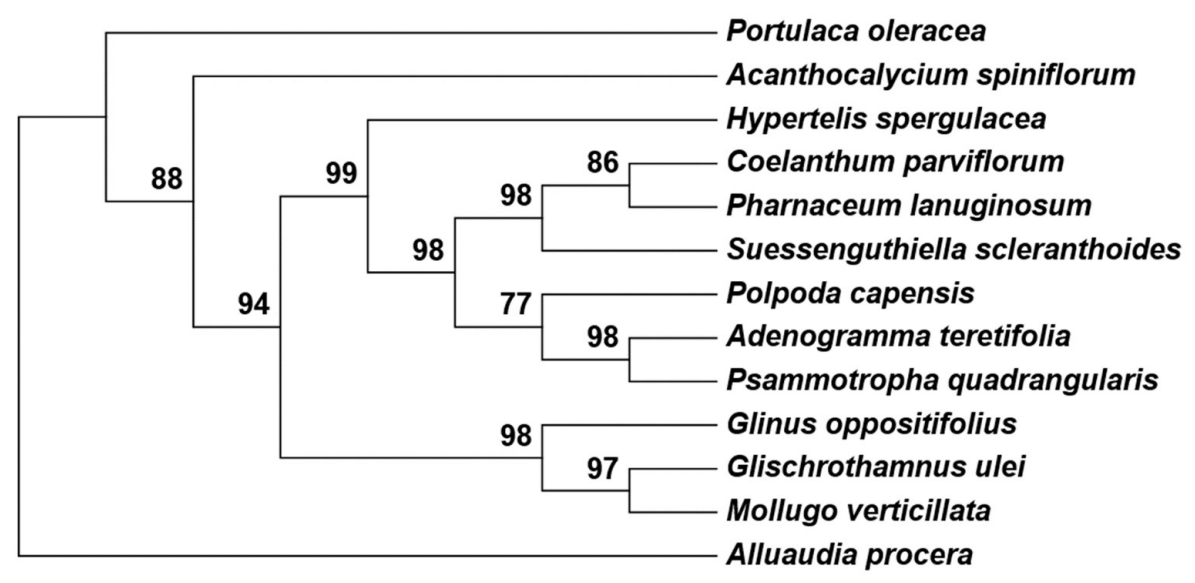

Figure 1. The bootstrap strict consensus of three maximally parsimonious trees of Molluginaceae based on molecular phylogenetic analysis of matK sequence. The bootstrap supports at the node more than $50 \%$ in 500 replicates have been shown above lines.

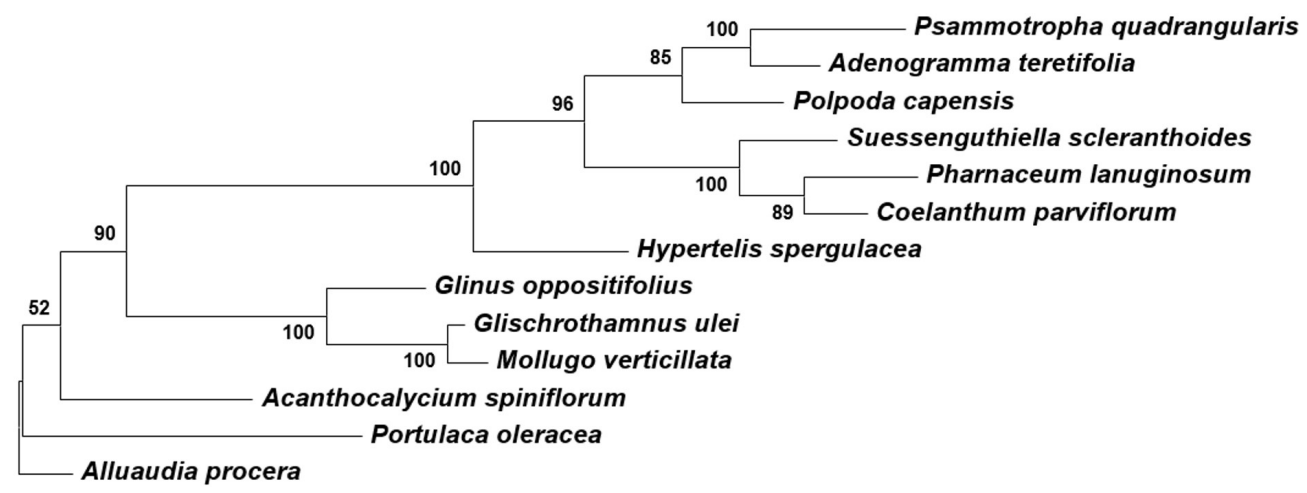

Figure 2. The maximum likelihood tree of Molluginaceae based on molecular phylogenetic analysis of matK sequences. The number at node indicates bootstrap supports.

Genetics and Molecular Research 16 (2): gmr16029295 
The resulting bootstrap (BS) strict consensus MPT and maximum likelihood tree (MLT) rooted at outgroup A. procera confirmed the polyphyly of Molluginaceae [88\% BS (MPT), 90\% BS (MLT)]. The MPT revealed that the basal clade of $P$. oleracea (Portulacaceae) and the A. spiniflorum (Cactaceae) clade show proximity [88\% BS (MPT), 52\% BS (MLT)] with the genera of the family Molluginaceae, which were grouped together in the clade [94\% BS (MPT), 90\% BS (MLT)]. In the Molluginaceae clade, there were three distinct subclades. The family Molluginaceae is sometimes partially or completely treated along with Aizoaceae and Phytolaccaceae. However, Molluginaceae differs in its absence of betalains, presence of anthocyanins and that is typically has free sepals. The synapomorphies known for Molluginaceae are lacking (Endress and Bittrich, 1993). Thus, in the traditional sense, Molluginaceae is polyphyletic (Cuénoud et al., 2002; Angiosperm Phylogeny Group, 2009; Christenhusz et al., 2014).

The subclade I consisted of M. verticillata, G. ulei, G. oppositifolius [98\% BS (MPT), 100\% BS (MLT)]. The G. oppositifolius (generic synopsis: stipules absent) shows close relationship to G. ulei (generic synopsis: dioecious (sub) shrubs, ovules 7-8 per locule) and $M$. verticillata (generic synopsis: locules 3-5, ovules many per locule).

The subclade II consists of $H$. spergulacea, $C$. parviflorus, $P$. lanuginosum, $S$. scleranthoides, P. capensis, A. teretifolia, and P. quadrangularis [99\% BS (MPT), 100\% BS (MLT)]. Among the subclade II, H. spergulacea makes the subclade polyphyletic with the rest of the six taxa of the subclade i.e. P. quadrangularis, A. teretifolia, P. capensis, $S$. scleranthoides, P. lanuginosum, and C. parviflorum. Among these taxon, S. scleranthoides (generic synopsis: stipules conspicuous, sepals hooded, ovules many per locule) shows proximity [98\% BS (MPT), 100\% BS (MLT)] with C. parviflorum (generic synopsis: sepals fused) and P. lanuginosum (generic synopsis: sometimes stipules, locules 3-5, ovules many per locule). C. parviflorum shows close relationship with P. lanuginosum [86\% BS (MPT), 89\% BS (MLT)]. While P. capensis (generic synopsis: sepals white, fringed; locules 2, ovule 1 per locule) shows close proximity [77\% BS (MPT), 85\% BS (MLT)] with A. teretifolia (generic synopsis: petals white, locule 1, ovule 1) and P. quadrangularis (generic synopsis: Perennials, stipules conspicuous, locules 3-5, ovule 1 per locule), A. teretifolia and P. quadrangularis clade together [98\% BS (MPT), 100\% BS (MLT)].

The genus Hypertelis was found to be polyphyletic in a previous study (Christin et al., 2011). H. spergulacea was found to be placed inside Molluginaceae s.s., and was nested within Mollugo, from which it was segregated based on its fleshy leaves with large stipules adnate to the leaf base and clasping the stem. This relationship was later supported based on single-copy nuclear genes and multiple plastid markers (Christin et al., 2011). The genus Mollugo is also polyphyletic within the family Molluginaceae (Arakaki et al., 2011; Christin et al., 2011).

In conclusion, the present molecular phylogenetic analyses revealed the polyphyly of the family Molluginaceae. Hypertelis was found at the base of the Molluginaceae clade. The genus Glinus is close to Glischrothamnus and Mollugo, Suessenguthiella showed proximity with Coelanthum and Pharnaceum, and Polpoda grouped with Adenogramma and Psammotropha.

\section{Conflicts of interest}

The authors declare no conflict of interest.

Genetics and Molecular Research 16 (2): gmr16029295 


\section{ACKNOWLEDGMENTS}

Research supported by research fund of Chungnam National University, Daejeon, Republic of Korea. Research supported by the King Saud University, Deanship of Scientific Research, College of Science, Research Center.

\section{REFERENCES}

Ajmal Ali M, Gyulai G, Hidvégi N, Kerti B, et al. (2014). The changing epitome of species identification - DNA barcoding. Saudi J. Biol. Sci. 21: 204-231 http://www.sciencedirect.com/science/article/pii/S1319562X14000321. https://doi. org/10.1016/j.sjbs.2014.03.003

Angiosperm Phylogeny Group (2009). An update of the angiosperm phylogeny group classification for the orders and families of flowering plants: APG III. Bot. J. Linn. Soc. 161: 105-121 https://doi.org/10.1111/j.1095$\underline{8339.2009 .00996 . x}$.

Arakaki M, Christin PA, Nyffeler R, Lendel A, et al. (2011). Contemporaneous and recent radiations of the world's major succulent plant lineages. Proc. Natl. Acad. Sci. USA 108: 8379-8384 http://www.pnas.org/content/108/20/8379. https://doi.org/10.1073/pnas. 1100628108

Brockington SF, Walker RH, Glover BJ, Soltis PS, et al. (2011). Complex pigment evolution in the Caryophyllales. New Phytol. 190: 854-864 http://onlinelibrary.wiley.com/doi/10.1111/j.1469-8137.2011.03687.x/full. https:/doi. org/10.1111/j.1469-8137.2011.03687.x

Christenhusz MJM, Brockington SF, Christin PA and Sage RF (2014). On the disintergration of Molluginaceae: a new genus and family (Kewa, Kewaceae) segregated from Hypertelis, and placement of Macarthuria in Macarthuriaceae. Phytotaxa 181: 238-242 http://biotaxa.org/Phytotaxa/article/view/phytotaxa.181.4.4. https://doi.org/10.11646/ phytotaxa.181.4.4

Christin P-A, Sage TL, Edwards EJ, Ogburn RM, et al. (2011). Complex evolutionary transitions and the significance of $\left.\left.\mathrm{c}_{3}\right)-\mathrm{c}_{4}\right)$ intermediate forms of photosynthesis in Molluginaceae. Evolution 65: 643-660 http://onlinelibrary.wiley. com/doi/10.1111/j.1558-5646.2010.01168.x/abstract. https://doi.org/10.1111/j.1558-5646.2010.01168.x

Cuénoud P, Savolainen V, Chatrou LW, Powell M, et al. (2002). Molecular phylogenetics of Caryophyllales based on nuclear 18S rDNA and plastid rbcL, atpB, and matK DNA sequences. Am. J. Bot. 89: 132-144 http://www.amjbot. org/content/89/1/132. https://doi.org/10.3732/ajb.89.1.132

Eck RV and Dayhoff MO (1966). Atlas of protein sequence and structure. National Biomedical Research Foundation, Silver Springs, Maryland.

Endress ME and Bittrich V (1993). Molluginaceae. In: The families and genera of vascular plants (Kubitzki K, ed.). vol. 2. Springer-Verlag, Heidelberg, 419-426. http://www.springer.com/series/1306

Felsenstein J (1985). Confidence limits on phylogenies: an approach using the bootstrap. Evolution 39: 783-791 https:// www.jstor.org/stable/2408678. https://doi.org/10.2307/2408678

Hilu K and Liang H (1997). The matK gene: sequence variation and application in plant systematics. Am. J. Bot. 84: 830839. https://doi.org/10.2307/2445819

Hilu KW, Borsch T, Müller K, Soltis DE, et al. (2003). Angiosperm phylogeny based on matK sequence information. Am. J. Bot. 90: 1758-1776 http://www.amjbot.org/content/90/12/1758.full. https://doi.org/10.3732/ajb.90.12.1758

Johnson LA and Soltis DE (1994). matK DNA sequences and phylogenetic reconstruction in Saxifragaceae s. str. Syst. Bot. 19: 143-156. https://doi.org/10.2307/2419718

Kar P, Goyal AK and Sen A (2015). MaturaseK gene in plant DNA barcoding and phylogenetics. In: Plant DNA Barcoding and Phylogenetics (Ali MA, Gabor G and Al-Hemaid F, eds.), Lambert Academic Publishing, Germany, 75-86.

Lee J, Kim SY, Park SH and Ali MA (2013). Molecular phylogenetic relationships among members of the family Phytolaccaceae sensu lato inferred from internal transcribed spacer sequences of nuclear ribosomal DNA. Genet. Mol. Res. 12: 4515-4525 https://doi.org/10.4238/2013.February.28.15.

Nei M and Kumar S (2000). Molecular evolution and phylogenetics. Oxford University Press, New York.

Nyffeler R and Eggli U (2010). Disintegrating Portulacaceae: a new familial classification of the suborder Portulacineae (Caryophyllales) based on molecular and morphological data. Taxon 59: 227-240 https://www.jstor.org/ stable/27757065?seq=1\#page_scan_tab_contents.

Nyffeler R, Eggli U, Ogburn M and Edwards E (2008). Variations on a theme: repeated evolution of succulent life forms in the Portulacineae (Caryophyllales). Haseltonia 14: 26-36 http://www.bioone.org/doi/abs/10.2985/1070-004814.1.26. https://doi.org/10.2985/1070-0048-14.1.26

Genetics and Molecular Research 16 (2): gmr16029295 
Olmstead RG and Palmer JD (1994). Chloroplast DNA systematics: a review of methods and data analysis. Am. J. Bot. 81: 1205-1224. https://doi.org/10.2307/2445483

Soltis DE and Soltis PS (1998). Choosing an approach and an appropriate gene for phylogenetic analysis. In: Molecular systematics of plants II: DNA sequencing (Soltis DE, Soltis PS and Doyle JJ, eds.). Kluwer Academic Publishers, Boston. 2-31.

Sugita M, Shinozaki K and Sugiura M (1985). Tobacco chloroplast tRNA(UUU) gene contains a 2.5-kilobase-pair intron: An open reading frame and a conserved boundary sequence in the intron. Proc. Natl. Acad. Sci. USA 82: 3557-3561. https://doi.org/10.1073/pnas.82.11.3557

Sukhorukov AP, Mavrodiev EV, Struwig M, Nilova MV, et al. (2015). One-seeded fruits in the core Caryophyllales: their origin and structural diversity. PLoS One 10: e0117974 https://doi.org/10.1371/journal.pone.0117974.

Tamura K, Peterson D, Peterson N, Stecher G, et al. (2011). MEGA5: molecular evolutionary genetics analysis using maximum likelihood, evolutionary distance, and maximum parsimony methods. Mol. Biol. Evol. 28: 2731-2739 http://mbe.oxfordjournals.org/content/28/10/2731.long. https://doi.org/10.1093/molbev/msr121

Thompson JD, Gibson TJ, Plewniak F, Jeanmougin F, et al. (1997). The CLUSTAL_X windows interface: flexible strategies for multiple sequence alignment aided by quality analysis tools. Nucleic Acids Res. 25: 4876-4882 http:// nar.oxfordjournals.org/content/25/24/4876.long. https://doi.org/10.1093/nar/25.24.4876

Genetics and Molecular Research 16 (2): gmr16029295 